\title{
KEGIATAN PENGOLAHAN DOKUMEN DI BAGIAN INFORMATIKA PADA SEKRETARIAT DAERAH KABUPATEN SUMBA BARAT
}

\author{
Simson P.E. Baok ${ }^{1}$, Agung Budiono ${ }^{2}$, Saleha Rodiah $^{3}$ \\ ${ }^{1}$ Setda Kab. Sumba Barat Daya, ${ }^{2,3}$ Program Studi Ilmu Perpustakaan Fikom Unpad \\ 1rato_babe@yahoo.co.id, ${ }^{2}$ agung.budiono@unpad.ac.id, ${ }^{3}$ saleda.rodiah@unpad.ac.id
}

\begin{abstract}
This study aims to analyze how the document management activities in section information at the Secretariat District of West Sumba. The purpose of this study to find out how the document management activities in sub-section data input, telematics sub-section, sub-section data services. The method used in this study is qualitative research methods. Type of research by the author is a descriptive study. Data collection techniques used were interviews, observation, library research, triangulation of data, and documentation. Subject in this study is the head of telematics, telematics data, input data, data services Kasubag, Academian of documentation, and archival Unpad. The informants were interviewed in person and via telephone. These result indicate that the document management activities in Section Information the secretariat of the West Sumba District already works quite well particularly confidential documents but in practice there are still many obstacles both in terms of collection of docu- ments, turning up to meet documents are still not well due to lack of facilities and infra- structures are still processing the document.
\end{abstract}

Keywords: Document Management, Secretariat District, West Sumba

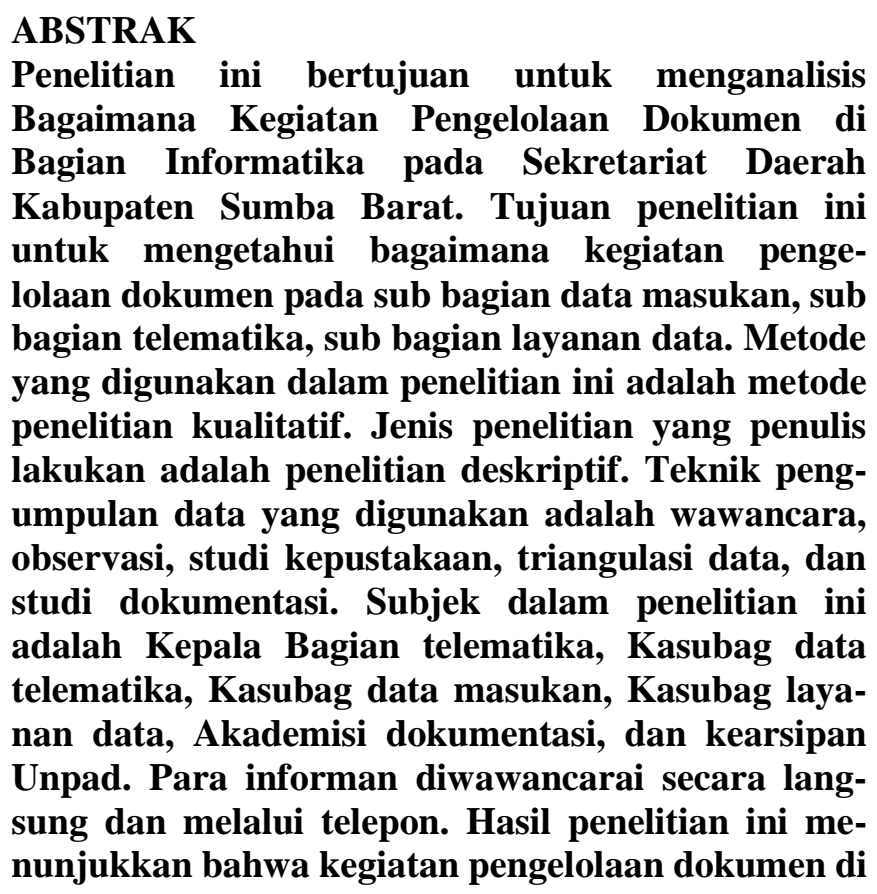

Bagian Informatika pada Sekretariat Daerah Kabupaten Sumba Barat sudah berjalan dengan cukup baik terutama dokumen rahasia namun dalam pelaksanaannya masih banyak kendala baik dari segi pengumpulan dokumen, sampai dengan temu balik dokumen masih belum baik dikarenakan masih kurangnya sarana dan prasarana pengolahan dokumen.

Kata kunci: Manajemen Dokumen, Sekretariat Daerah, Sumba Barat

\section{PENDAHULUAN}

Perkembangan informasi pada saat sekarang ini sangat penting seiring dengan kemajuan zaman. Informasi merupakan kebutuhan bagi masyarakat luas, bahkan masyarakat yang modern ini dapat terancam kelangsungan hidupnya apabila tidak mendapatkan informasi. Dengan informasi manusia dapat mengetahui kejadian yang terjadi di sekitar maupun di luar lingkungannya, dapat mencerdaskan kehidupannya, memperluas cakrawala pandangannya, serta peranan dalam masyarakat.

Sebagai masyarakat informasi yang membutuhkan informasi dan menyimpan ribuan informasi terekam dan terus berkembang, tetapi tidak seluruh orang dapat mengikuti seluruh perkembangan dan pertumbuhan informasi, apabila jika informasi tidak ada yang mengelolanya secara khusus, atas alasan-alasan yang disebut tadi, pada ilmu informasi dan perpustakaan mempelajari bagaimana cara mengelola, mengolah, dan 
mendistribusikan informasi, dan memanfaatkan informasi kelolaannya kepada orang yang membutuhkannya, dari sudut pandang dunia perpustakaan informasi adalah suatu rekaman fenomena yang diamati, atau bisa juga berupa putusan-putusan yang dibuat seseorang.

Melihat penjelasan di atas kegiatan penyimpanan data sangatlah penting bagi sebuah organisasi termasuk instansi pemerintahan pada Kabupaten Sumba Barat maka kegiatan penyimpanan data juga dilaksanakan oleh Kantor Penyimpanan Data Elektronik (KPED) pada Sekretariat Daerah (SETDA) Kabupaten Sumba Barat yang terbentuk dengan Peraturan Daerah Nomor 3 Tahun 2001, tentang Pembentukan Susunan Organisasi dan Tata Kerja Perangkat Kerja Perangkat Kerja Daerah Kabupaten Sumba Barat, yang sekarang di sederhanakan dengan Peraturan Daerah (PERDA) Nomor 8 tahun 2007 tentang Pembentukan Organisasi dan Tata Kerja Sekretariat Daerah menjadi bagian informatika sehingga kebutuhan akan informasi dengan cepat dapat ditelusur oleh semua instansi pemerintahan yang ada di kabupaten Sumba Barat, mulai dari pengadaan dokumen, mengelola, menyimpan, dan penelusuran informasi.

\section{TINJAUAN PUSTAKA}

Dokumen merupakan semua jenis fisik yang mengandung informasi (Soejono, 1987, 2). Sedangkan menurut Martono (1987, 2), dokumen merupakan benda-benda yang bernilai informasi seperti lembaran tercetak, bergambar, berukur, terpahat, struktur informasi, papan statistik, tata kerja, denah/maket gedung dan sebagainya dapat di kategorikan sebagai dokumen.
Menurut Ridwan (2011) jenis dokumen dibagi sebagai berikut:

I. Jenis-Jenis Dokumen Berdasarkan Kepentingannya

a) Dokumen pribadi, yaitu dokumen yang menyangkut kepentingan perorangan. Contohnya: KTP, SIM, dan Ijazah.

b) Dokumen niaga, yaitu dokumen yang berkaitan dengan perniagaan. Contohnya: cek, obligasi, dan saham.

c) Dokumen sejarah, yaitu dokumen yang berkaitan dengan sejarah. Contohnya: fosil, tugu, dan naskah proklamasi.

d) Dokumen pemerintah, yaitu dokumen yang berisi tentang informasi ketatanegaraan suatu pemerintahan. Contohnya: Keppres dan UU.

II. Jenis-Jenis Dokumen Berdasarkan Bentuk Fisiknya

a) Dokumen literer adalah dokumen yang ada karena dicetak, ditulis, digambar, atau direkam (dikumpulkan di perpustakaan). Contoh: buku, majalah, film.

b) Dokumen korporil adalah dokumen yang berupa benda bersejarah (dokumen ini dikumpulkan di meseum).

c) Dokumen privat adalah dokumen yang berupa surat atau arsip (disimpan dengan sistem kearsipan).

Sistem penyimpanan dokumen adalah sistem yang digunakan dalam penyimpanan warkat agar kemudahan kerja penyimpanan dapat diciptakan dan penemuan warkat yang sudah disimpan dapat dilakukan dengan cepat bersama warkat tersebut sewaktu-waktu diperlukan (Amsyah, 2003, 71) 
Beberapa langkah pengelolaan dokumen meliputi pemeriksaan atas dokumen-dokumen tersebut sampai mereka disusun pada masingmasing tempat penyimpanan dokumen menurut jenisnya masing-masing. Dalam Vardiatama (2009) urutan langkahnya adalah:

1. Pemeriksaan atas dokumen yang rusak

a. Dokumen tersebut sesuai dengan yang dipesan atau yang dibutuhka oleh lembaga yang bersangkutan atau tidak ditinjau dari segi materinya, kemutakhiran data atau faktanya, kompetensi atau kualifikasi ataupun kewenangan penyusunnya, bentuk fisiknya (hardcover atau bukan) dan spesifikasi lainnya yang ditetapkan sebelumnya.

b. Kondisi dokumen: lengkap atau tidak halamannya, tipografinya jelas atau tidak, gambar-gambarnya, grafik lampiran yang kurang lengkap, dsb.

c. Menyortir dokumen-dokumen yang masuk itu menurut kelompok jenisnya (buku, pamflet, brosur, leaflet, manuskrip, dst.) untuk memudagkan penyelesaian administrasi (pembayaran rekening penagihan untuk mereka, pembuatan surat-surat jawaban, dsb.), serta untuk kepentingan pemrosesan dokumen selanjutnya : inventarisasi, katalogisasi/ pengindeksan, abstracting, dst.

2. Langkah-langkah inventarisasi dokumen

a. Semua jenis dokumen tanpa terkecuali harus dibubuhi tanda cap instansi atau lembaga yang bersangkutan agar dapat diketahui dengan segera bahwa barang tersebut adalah milik lembaga yang bersangkutan, untuk dokumen tertentu seperti film, microfilm dan sebagainya cap dibubuhkan pada label yang ada pada kotak atau sampulnya.

b. Pada sisi halaman belakang judul hendaknya diterapkan cap agenda: tanggal penerimaan dokumen, nomor induk atau accesion number (untuk dokumen yang berupa buku) dan keterangan-keterangan yang dianggap perlu, misalkan: harga buku, keterangan seperti sumbangan, hadiah, dan sebagainya.

c. Registrasikan dokumen tersebut dibagi menjadi tiga penanganan yakni dokumen yang berupa buku, berupa majalah atau harian, serta untuk dokumen yang berupa pamflet/brosur/ leaflet.

d. Pembuatan katalog, indeks, dan abstraksi.

3. Sistem penyimpanan arsip (Filling)

Terdapat banyak cara penyimpanan arsip (filling) yang digunakan di lembaga-lembaga dan kantor-kantor untuk saat ini trendnya adalah arsip disimpan secara sistematis dalam bentuk digital.

\section{METODE PENELITIAN}

Metode yang digunakan dalam penelitian ini adalah metode kualitatif deskriptif. Menurut Bodgan dan Taylor, penelitian kualitatif didefinisikan sebagai prosedur penelitian yang menghasilkan data deskriptif berupa kata-kata tertulis atau lisan dari orang-orang dan perilaku yang diamati. Pendekatan ini diarahkan pada latar dan individu tersebut secara holistik (utuh). Metode ini hanya memaparkan siatuasi secara sistematis, tidak menceritakan atau menjelaskan hubugan, tidak 
menguji hipotesis atau membuat prediksi (Rakhmat, 1991, 24).

\section{HASIL DAN PEMBAHASAN}

Setelah peneliti mengamati melalui kegiatan pengumpulan data dan wawancara, peneliti mencoba untuk menganalisis kegiatan pengolahan dokumen di Bagian Informatika pada Setda Kabupaten Sumba Barat, untuk memperoleh data tentang fokus penelitian, peneliti melakukan wawancara dengan beberapa informan yang ada di Bagian Informatika ada Sekretariat Daerah Kabupaten Sumba Barat dan informan dari Fakultas Ilmu Komunikasi (Fikom) Unpad.

Hasil pengamatan di lapangan terlihat bahwa bagian Informatika pada Sekretariat Kabupaten Sumba Barat merupakan salah satu bagian penting dalam struktur pemerintahan di Sumba Barat merupakan dalam proses penyelenggaraan pemerintahan dalam bidang informatika harus mampu memberikan pelayanan dan menyediakan informasi yang akurat sesuai dengan tugas dan fungsi yang diemban. Dengan adanya bagian informatika maka diharapkan dapat membantu Bupati dalam menjalankan roda pemerintahan di kabupaten Sumba Barat.

Ditinjau dari aspek Sumber Daya Manusia dalam pelayanan terhadap pengguna informasi, bagian informatika mempunyai tiga sub bagian dan memiliki tujuh orang Pegawai Negeri Sipil (PNS) serta dua orang tenaga kontrak namun demikian bagian informatika menerapkan prinsip- prinsip layanan antara lain layanan harus sesuai dengan kebutuhan penggunaan data, diusahakan berlangsung dengan cepat, tepat dan mudah serta menciptakan kesan yang menarik dan menyenangkan dan memuaskan pengguna.

Pengelolaan dokumen merupakan suatu kegiatan pengumpulan dokumen yang mengikuti rangkaian dokumenter antara lain: analisis kebutuhan dokumen, seleksi dokumen, inventarisasi dokumen, verifikasi dokumen, layanan sampai dengan pemanfaatan dokumen dan bisa menjawab kebutuhan informasi dari pengguna.

Dalam kegiatan pengelolaan dokumen kualifikasi pegawai merupakan unsur penting, karena keberlangsungan pengolahan dokumen dan keselamatan dokumen terutama informasi yang ada di dalamnya harus ditangani oleh pegawai-pegawai yang mempunyai keahlian khusus seperti arsiparis.

Alih bentuk dokumen adalah untuk mengatasi begitu banyaknya dokumen adalah untuk mengatasi begitu banyaknya dokumen yang ada ada suatu organisasi ke dalam bentuk lain seperti $\mathrm{CD}$, dengan tidak merubah keaslian isi atau informasi yang ada dalam dokumen tersebut, dalam melaksanakan kegiatan pengelolaan doku- men diperlukan sarana dan prasana untuk menyim- pan dan memelihara dokumen itu sendiri, tempat penyimpanan dokumen yang baik dapat menjaga keberadaan suatu informasi yang terkandung dalam dokumen itu sendiri.

Temu balik suatu dokumen sangat berkaitan dengan manajemen dokumen dan sistem penyimpanannya sehingga keakuratan informasi yang terkandung di dalam dokumen dapat dimanfaatkan sesuai dengan kegunaan dan informasi yang terkandung dalam dokumen tersebut.

Anggaran merupakan faktor utama dalam pengelolaan dokumen pada suatu organisasi. Pengelolaan dokumen sangatlah berpengaruh besar 
terhadap besar kecilnya alokasi anggaran dan berpengaruh besar terhadap besar kecilnya alokasi anggaran dan berpengaruh juga kepada sarana dan prasarana penunjang pengelolaan dokumen.

Pemantauan dan pengendalian terhadap dokumen sangatlah penting dengan maksud agar mendokumen tersebut dapat digunakan sesuai dengan peruntukannya sehingga dokumendokumen tidak disalahguanakan oleh orang yang tidak bertanggung jawab.

Keberadaan dokumen sangatlah penting terutama informasi yang terkandung di dalamnya. Untuk itu, dokumen harus dipelihara dengan baik, tujuan pemeliharaan adalah untuk melindungi, mengatasi dan mengambil tindakan untuk menyelamatkan informasi di dalamnya juga menjaga keberlangsungan hidup fisik dokumen tersebut.

Pengamanan dokumen yang bersifat rahasia merupakan usaha penjagaan dokumen agar tidak hilang dan isi informasinya tidak sampai diketahui oleh orang yang tidak berhak mengetahuinya, petugas dituntut untuk bisa untuk mengetahui persis mana saja dokumen yang sangat vital bagi organisasinya mana dokumen yang tidak terlalu penting, mana dokumen yang sangat rahasia, dan lain sebagainya.

\section{SIMPULAN}

Berdasarkan hasil penelitian yang telah dilaksanakan analisa yang telah diuraikan sebelumnya peneliti menarik kesimpulan bahwa:

1. Pembagian tugas pengolahan dokumen pada

Bagian Informatika berjalan sesuai dengan tupoksi masing-masing sub bagian: Sub Bagian Data Masukan, Sub Bagian Telematika, Sub Bagian Layanan Data.
2. Kegiatan pengolahan dokumen di Bagian Informatika pada sekretariat Daerah Kabupaten Sumba Barat sudah berjalan dengan cukup baik terutama dokumen rahasia namun dalam pelaksanaannya masih banyak kendala baik dari segi pengumpulan dokumen, sampai dengan temu balik dokumen masih belum baik dikarenakan masih kurangnya sarana dan prasarana pengolahan dokumen.

Kesiapan anggaran dan pegawai belum memadai untuk kegiatan pengolahan dokumen bagian informatika, sehingga pelaksanaan pengolahan dokumen masih dikatakan kurang baik.

\section{DAFTAR PUSTAKA}

Amsyah, Zulkifli. (2003). Manajemen Kearsipan Modern. Jakarta: Gramedia Pustaka Utama Martono, E. (1987). Manajemen Kepegawaian. Jakarta: Departemen Pendidikan dan Kebudayaan

Trimo, Soejono. (1987). Pengantar Ilmu Dokumentasi. Bandung: Remadja Karya

Rakhmat, Jalaluddin. (1991). Metode Penelitian Komunikasi. Bandung: PT Remaja Rosdakarya.

Ridwan. (2011). Jenis-Jenis Dokumen. http://ridwanjuli.blogspot.co.id/2011/06/jenis -jenis-dokumen.html.

Varditama. (2009). Proses Pengolahan Dokumen. http://kuliahilmuinformasidanperpustakaan.b logspot.co.id/2009/12/proses-pengolahan-do kumen.html. 
